\title{
Preserving The Uniqueness of English Teaching at Early Childhood Education
}

\author{
Bambang Harmanto \\ Ponorogo Muhammadiyah University, Jl. Budi Utomo 10 Ponorogo \\ \{bambange.unmuhpo@gmail.com\}
}

\begin{abstract}
The way of early childhood teachers in introducing English to their students often seems to be unique. With a limited knowledge and skill, they have to be competent English practioners. The learning outcome migh not be optimal as the parents expected. The writer has raised questions regarding what early chilhood teachers should know and the skills they need to teach English in early chilhood education. This identified need was able to be the basic consideration to help the early childhood teachers have capacity of teaching appropriately. The researcher findings drwn on the questionnaire distributed to 31 early eduaction teachers in Ponorogo. Data findings showed that eventhough their education backgrounds were not suitable with the subject they teach, they will welcome conveniently the offerred breakthrough. They were open to receive any programs to enhance their capacities of teaching skills and attributes they require or knowledge they need.
\end{abstract}

Keywords. Uniqueness, Early childhood eduaction, Capacities, English for Early Childhood.

\section{INTRODUCTION}

English to young learners mainly in early childhood education in Ponorogo is already formally introduced by the teachers. However, Rahmat (2010) explicitly stated that even today many countries in the world, including Indonesia, have started learning foreign languages, especially English, Mandarin or Arabic as foreign languages in early childhood the results are not satisfactory. They have not been able to express it in daily life. Their needs are still limited to getting score rather than the communicative competence. It might be caused by the teacher's readiness to teach on English as what have said by Copland, Garton, and Burns (2014) that one of the most complex of the policy decisions affecting young learner classrooms concerns pedagogy. They admitted through informal interview that they feel less confident and are not able to carry out learning in accordance with expectations. Most of them said that they did not have an English education background. With this condition, it will certainly be a problem both from the pedagogical and linguistic aspects. It was very unique. By reason of the school prestige, English was introduced with some restrictiveness on the human resources. It, of course, is going to be a heavy burden for early chilhood teachers who have limited knowledge and skill to teach it. Consequently, the teaching might not be optimal which lead the children tend to be less happy and find it difficult to learn English.

As we all have known that in this era of mastering foreign languages, especially English, is a very important requirement. Various fields of work such as trade, industry, transportation, and others have used English as a means of communication in order to establish networks with 
a wider range. Moreover, the presence of the internet which uses more English has made it a communication medium that can help them to develop and maintain their business to the maximum extent amid intense competition. You hear it on television spoken by politicians from all over the world. Wherever you travel, you see English signs and advertisements. Whenever you enter a hotel or restaurant in a foreign city, they will understand English, and there will be an English menu. (Crystal, 2003).

Linked to the issue of the teachers' pedagogy, although they have limited knowledge of teaching techniques, unlikely they were forced to own the power to choose a variety of learning models that are appropriate to the abilities and learning styles of early childhood and in a happy and comfortable atmosphere. According to Haenilah (2015) the role of early childhood education is not only as a teacher but as a model, figure, or role model that every day is seen, heard and imitated by children. Learning must be able to provide an environment that is rich in sensory stimulation so that all potential children can develop optimally. Young learner, those attending preschool or kindergarten will not have any personal reason for studying English. At this point they may not know or comprehend how important these classes can be. They might view the class as simply an other fun daily activity and that is just fine. Therefore, to get better target of English learning, teachers should keep everything as simple and short as possible. The students do not have long attention spans and easily distracted. They also must be aware of the challenges and difficulties they may encounter, and prepare accordingly.

This paper will describe evidently the real responses of the early childhood teachers related to the readiness on introducing English to their students. Identifying the needs of the early childhood education teachers finally is important in supporting the efforts to develop English effectively. China has learnt from the best advances in early childhood education curriculum studies around the world and is now moving to a position where local conditions and Chinese research will help advance reform. (Fan, et.al, 2016). In the context of Indonesian, it is in line with Suyanto's proposal (2007) in which the substance of foreign / second language learning activities included competencies and language skills such as listening, speaking (speaking), reading (reading), and writing (writing). These skills are taught integratively and integrated with what happens in everyday life. The concepts that need to be mastered by children in language are 1) identification (getting to know people / objects around children), 2) classification (grouping, for example color, shape, size, number, function, type, etc. .), 3) spatial (space or position of people / objects), 4) temporal (time), 5) emotional (feelings), 6) familial (family), 7) ordering (composing), and 8) equivalence (comparison) .

Another alternative solution is that relates to the method / method / strategy employed by the teacher in introducing foreign languages in early childhood. Moon (2000) propossed some teaching techniques can be adopted such as: 1) naturally, the same as the way they learn mother tongue, 2) children need to be motivated and distimulus, 3) activities that are listening and repeating repeat, 4) activities by imitating the teacher, 5) activities by interacting with others, and activities that translate from mother tongue to foreign language and vice versa. Davison (nd) in Harmanto (2015) also suggests that educators can change the way they teach by creating activities as follows: creating Web quests, creating technology-based simulations , reduce lecture time, increase discussion, provide ready-to-use internet, design group work, create Inquiry based learning models, teach a little memorization of many interactions, and apply blog or Wikipedia classes. In addition, Shin (2006) gave another recomendation about the appropriate and relevant methods / strategies can teacher use in the process of learning foreign languages for early childhood such as 1) using gestures and flashcards, 2) using games, 3) using music, songs, and chants, 4) using dance and movement, 5) using dialogue, 
dama, and poetry, 6) using stories and storytelling, 7) using crafts and activities, 8) project work, 9) using technology in the classroom, and 10) pair and group work. It should be noted in conducting foreign language learning activities for early childhood so that learning can achieve the objectives as expected: 1) complement learning activities with visual media, realia and movements and a combination of spoken language with 'body language' or 'demonstration' For example, a teacher wants to give vocabulary about animals. Then the teacher must show a picture or doll in the shape of an animal. With that it will be faster captured and understood by children. He underlines that the activities teacher plan have 1) involving children in making visual media or realia, 2) moving from one activity to another with fast, 3) building routines in the classroom using English, 4) using mother tongue when needed, 5) teaching based on themes and stimulating children's imagination and creativity, 6) using stories and contexts that are already known to children, 7) invite the surrounding community (parents, students, etc.) who can speak English to report in the classroom, 8) collaborate with other teachers in your school, and 9) communicate with the teacher or instructor for other early childhood outside of school.

It must be in the early childhood education teachers' mindset that when children enters preschool or kindergarten, they may not know English, but they have much experience using language. Learning to English all day with uninteresting method might be exhausting. Therefore, kindergarten or ECE teachers should encourage them by providing various approches. It is also important for the teacher to engage and interact with children when they introduce a foreign language. The teacher can make significant observations about children's adjustment, interactions with other children, use of classroom materials, and development of concepts during these times. It is one of the ways to preserve the ECE teachers to cultivate a positive attitude to children who have very little English.

\section{METHODOLOGY}

The design used in this research is survey technique in which the research subject was taken from early childhood education institution spreading in Ponorogo district which was under coordiantion of The Indonesian Kindergarten Teacher Association ( IGTKI) and The Indonesian Early Childhood Education Association (HIMPAUDI) as primary data source. The data was obtained through the questionnaires distributed to the respondens as many as 31 teachers. The questionnaire covers 7 questions dealing with their understanding of the benefits of learning English from an early age, their desire to be able to teach English to children early on properly, and their willingness to teach English to children from an early age seriously. The result of thee study was analyzed using a quantitaive descriptive approach. The analysis phase includes data reduction, data presentation, and conclusion drawing. Data reduction is done by selecting data that is relevant to the grid of questions, making summaries, and organizing data in such a way in the forms of percentage. In presenting data, data that has been collected is arranged in accordance with the formulation of the problem so that it is easy to increase conclusions. The form of presentation is in the form of narrative texts and charts to make it easier for readers to see what has happened. Whereas the conclusion is made by making explanations.

\section{FINDINGS AND DISCUSSION}

The finding focuses on the two main problems raised in this study: 1) Do the early childhood education teachers have English education background?, and 2) to what extend 
do the early childhood education teachers ready to teach English for their students? For the firs question of the teachers' education background was summarized as in the figure 1.

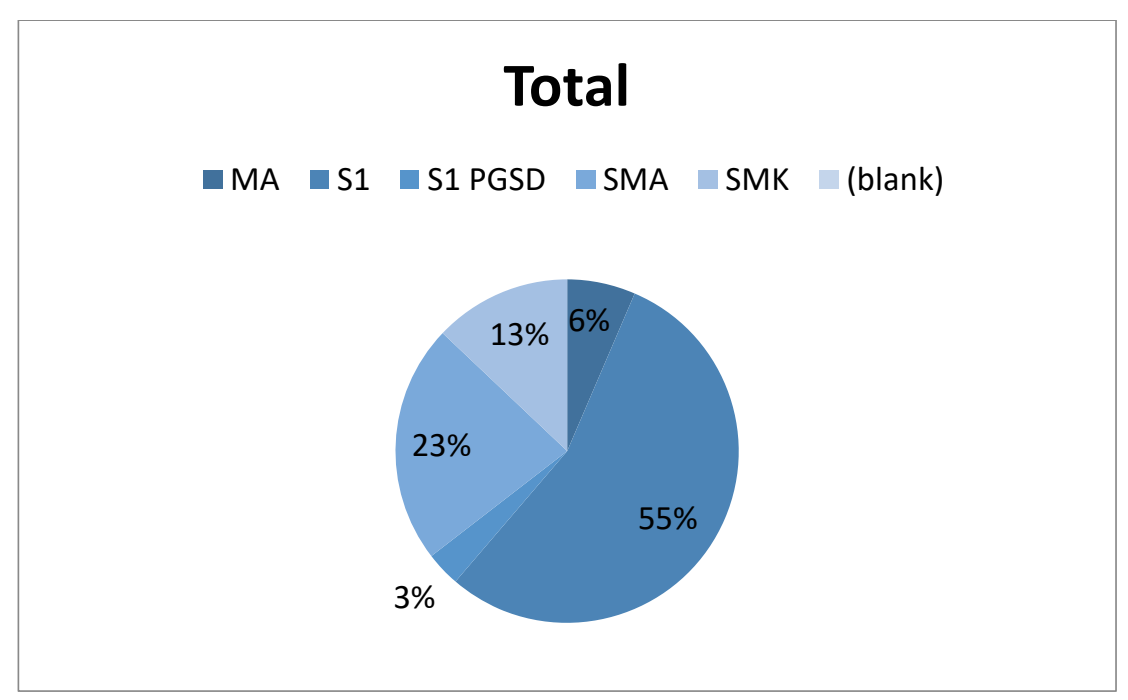

Fig. 1. Education Qualifcation of the Respondens

Based on the figure 1, it is clearly that the early childhood education background of education was various. As many as $58 \%$ respondeds were s1 degree holder and $42 \%$ teachers were Senior High school graduates. The data showed that the mojority of their education qualification did not match with what they wanted to teach including English subject. The data could not be the basis assumption that they do not know and like to the English because of their experience of studying previously. Their beliefs about English could not be negative judged. As stated by Qbeita (2011) who studied the ECE teachers' belief in Jordan has concluded that there are not statistically significant differences in the kindergarten teachers' beliefs about teaching English due to academic level (Diploma, Bachelor) could be interpreted that teachers' beliefs are not determined by the educational level, but they are convictions determined by the general trend toward English language teaching. Therefore, there are still a possibility to introduce English in early childhood education as long as they have a possitive view on English.

The data of second problem was discussed in Table 1. The respondens were asked to give their personal opinion related to their knowledge of English and their willingness to follow up the requirement for a better English practioner in their schools. The result of the responses were quantified in the forms of percentage.

Table 1. The percentage of Responses

\begin{tabular}{llccc}
\hline \multirow{2}{*}{ No } & \multicolumn{2}{c}{ Questions } & \multicolumn{3}{c}{ Responses } \\
\cline { 3 - 5 } & \multicolumn{1}{c}{ SA* } & A & DA \\
\hline 1 & $\begin{array}{l}\text { Do you know the benefits of learning English } \\
\text { from an early age? }\end{array}$ & $9,6 \%$ & $74,1 \%$ & $16,1 \%$ \\
2 & $\begin{array}{l}\text { Do you have the desire to be able to teach } \\
2\end{array}$ & $58 \%$ & $35,4 \%$ & $6,4 \%$
\end{tabular}


English to children early on properly?

3 Are you interested in English-language books for children?

$4 \quad$ Will you voluntarily provide time and funds to develop the science of teaching English to children from an early age?

$5 \quad$ Would you be happy if you take part in training activities on how to teach English to children from an early age?

$6 \quad$ Will you be happy with English? Do you know of an effective method of teaching

$19,3 \% \quad 74,1 \% \quad 6,4 \%$

$12,9 \% \quad 83,8 \% \quad 3,2 \%$

$12,9 \% \quad 77,4 \% \quad 9,6 \%$

$58 \% \quad 41,9 \%$

$32,2 \% \quad 67,7 \%$ English to children from an early age?

\section{*SA=Strongly Approve $\mathrm{A}=$ Approve $\mathrm{DA}=$ Disapprove}

Table 1 showes that the first question related to the teacher's knowledge of the benefits of learning English from an early age, there were only 3 teachers or $9.6 \%$ who knew very well. As many as 23 teachers or $74.1 \%$ know enough. The rest there are 5 people or $16.1 \%$ do not know about the benefits of learning English. It could be interprated that teachers of early childhood education are able to read the need of English for the children future. They might have realized the importance of English in the global era.

The second question clearly that the teachers' desire to teach English to children early is well there are as many as 18 teachers or $58 \%$ who are eager, and only 11 teachers or $35.4 \%$ who want to learn. While 2 teachers or $6.4 \%$ said they were less willing. It means more that half more than the teachers have strong motivation to learn how to introduce English earlier.

To support teacher competencies in developing English for children, for the third question, their responses to interest in English-language books for children, as many as 6 teachers or $19.3 \%$ said they were very interested. Meanwhile there were 23 teachers or $74.1 \%$ who were interested. While a number of 2 people or $6.4 \%$ are less interested in English books. The data can be assumed that the majority of teachers wanted to get the relevant source for teaching. It could help them overcome their problem of the teaching material development.

As a follow up to the forth question dealing the willingness of respondents to provide time and funds to develop the science of teaching English to children from an early age, as many as 4 people or $12.9 \%$ were very willing. While 26 people or $83.8 \%$ are willing to provide it. There is only 1 teacher or $3.2 \%$ say they are not willing. It clear that the teachers were well welcome for culturalizing the English for their student. They knew well about the challeges of the next generation.

Responding the fifth question, teachers were happy to take part in training activities on how to teach English to children from an early are as many as 4 people or $12.9 \%$. While those who were quite happy were 24 people or $77.4 \%$. Whereas 3 people or $9.6 \%$ are less happy with English. In other words, teachers of early childhood education were enthusiastic on English. They were very serious and open to develop the potency and capacity of teaching. It, of course, becomes a good triger for the teacher in making the English classroom atmosphere effectively.

For the sixth question about the teacher happiness with English, teachers who were very happy with English were as many there were 18 data or $58 \%$ said they were very happy. Whereas 13 teachers or $41.9 \%$ also expressed happy. It can be claimed that teachers of early childhood education were not allergic on English. They already had a possitive view on 
English. It, of course, becomes a good capital for the teacher in giving English lesson to the students.

Finally, in connection with the seventh questions about know of an effective method of teaching English to children from an early as many 32,2\% respondents were knew little. Meanwhile $67,7 \%$ of the teachers still did have enough knowledge about the method needed for introducting English at ECE. It seems be reasonable because they have not got the specific pedagogy of teaching English to young learner or early childhood. With the data, meaning that there are opportunities and potential to train the effective methods or strategy for early childhood education teachers so that they can popularize English well earlier.

\section{CONCLUSIONS}

Based on the answer to the major research question about how to preserve the uniqueness of early childhood education teachers in introduction English for their students, then the conclusions can be drawn as follows.

Firstly, regardless of the different education background early childhood education teachers might have equal ability to be "good" educator due to their experience of studying English at their former school. The basic English vocabulary needed to introduce English for preschool students must be well kept in their memory. They just need to refresh their mind for recalling the English inputs that ever been learnt for some time ago.

Secondly, eventhough English is not compulasary subject in early childhood education curriculum the teachers have own initiatives to introduce it due to their understanding of the globalization demands. They are fairly aware of their children future needs. Therefore, they are very open for any recommendation from outsider to build a good motivation and support the children learning English in order to gain the better future. Finally their "uniqueness" can be maintained by seting-up their attitudes and concerns that might be useful to help them as "good" English practioners.

\section{Acknowledgments}

This article is an output of a preliminary research done in small region in Ponorogo Indonesia to get a description of the early childhood education teachers' view on English as the foundation for constructing a system to improving their capacity of introducing English to preschool learners. The author would like to thank everybody for their help with compiling the corpus data and the institution which has given him a finacial support and opportunity.

\section{References}

[1] Crystal, David 2003. (2 nd Ed) English as a global language Cambridge, New York, Melbourne, Madrid, Cape Town, Singapore

[2] Harmanto, bambang.2015. Designing Exciting Learning for Digital Generation. Accessed from http://eprints.umpo.ac.id/1755/2/10 accessed on 15 June 2017

[3] Kasbolah, Kasiani. 2007. Teaching English in Primary Schools: policy, implementation, and reality. The paper was presented in the inauguration of the professor at the State University of Malang.

[4] Moon, Jayne. (2000). Children Learning English. Oxford: Macmillan Publishers Limited. Nissani, Helen. 1993. Early Childhood Programs for Language Minority Students

[5] Rahmat, Aceng. 2010. Implementation of Foreign Language Curriculum in DKI Jakarta Kindergarten (tk). Journal of Linguistic Studies and June 2010, vol. 22. no.1, 
[6] Shin, Joan Kang. (2006). Ten Helpful Ideas for Teaching English to Young Learners. English Teaching Forum, Volume 44, Number 2: 2-7

[7] Copland, Garton, and Burns. 2014. Challenges in Teaching English to Young Learners: Global Perspektives and Local Realities. TESOL QUARTERLY. Vol.48, No.4. December 2014. P. 738-762.

[8] Fan X., Nyland B., Nyland C., 2016. What Knowledge and Skills Do Chinese Kindergarten Teachers Need in a Time of Reform: Director's Perspectives Asia-Pacific Journal of Research In Early Childhood Education Vol.10, No.3, September 2016, pp.2748

[9] Asma'a Qbeita. 2011 Kindergarten Teachers' Beliefs about Teaching English in Jordan Asma'a Abu Qbeita. An - Najah Univ. J. Res. (Humanities). Vol. 25(5) p. 1435 - 1462

[10] California Department of Education. 2009. Supporting English Language Learners in Kindergarten A practical guide for Ontario educator. Sacramento 